\section{De 'schoolcoach': de link tussen ouders en school en tussen onderwijs en zorg}

M.M. Boere-Boonekamp, ${ }^{1}$ L.V. van Harten, ${ }^{1}$ R.M. Vink ${ }^{1}$ en P. Kocken ${ }^{1,2}$

Achtergrond en doelstelling De 'schoolcoach' is, naar Amerikaans concept van de 'family coach', een nieuwe professional in een pilotstudie op 3 basisscholen in Den Haag. De scholen en de gemeente beogen met deze professional een laagdrempelig aanspreekpunt te creëren voor ouders die vragen hebben over hun kind. De schoolcoaches hebben vaak een achtergrond als maatschappelijk werker, maar dat is niet vereist. De schoolcoaches kunnen worden gezien als een interventie ter preventie van ernstige psychosociale problemen bij kinderen. In dit onderzoek is de pilot geëvalueerd.

\section{Methode}

Er zijn 17 semigestructureerde interviews gehouden met professionals in het onderwijs- en zorgnetwerk van de 3 scholen die de schoolcoach hebben geïmplementeerd en met de leiding van 2 andere scholen die belangstelling toonden voor deelname aan de pilot. Verder zijn de activiteiten van de schoolcoach en de functiebeschrijvingen van vergelijkbare functionarissen geanalyseerd.

\section{Resultaten}

De schoolcoach blijkt te voorzien in een behoefte van ouders, scholen (leerkrachten, schoolleiding) en zorgverleners. De meerwaarde van de schoolcoach lijkt te berusten op de combinatie van een gemakkelijk en direct te benaderen aanspreekpunt voor ouders, los van school maar toch in de school, de proactieve houding naar ouders, en de focus op het betrekken van de gezinnen bij de school van het kind. De schoolcoach ondersteunt ouders om zelf hun problemen op te lossen en de controle te krijgen over hun opvoedingstaak. Andere professionals in en om de school geven aan dat met de komst van de schoolcoach hun werkdruk afneemt. Verbetering is nodig ten aanzien van: 1) vermijden dat de taken van de schoolcoach en die van andere functionarissen op school en in de wijk overlappen, 2) het nog beperkte aantal ouders dat wordt bereikt, 3) het beperkte aantal huisbezoeken dat wordt gebracht, 4) de verschillende registratiesystemen en 5) het omgaan met de privacy van leerlingen en ouders.

\section{Conclusies}

Het implementeren van een schoolcoach op basisscholen kan gunstig zijn voor kinderen en en voor het gezin waar zij opgroeien. Een betere omschrijving van de taken van de schoolcoach is noodzakelijk. Het combineren van bepaalde functies in en rond school kan de efficiëntie van de schoolcoach vergroten. Het is essentieel dat de schoolcoach goed toegankelijk blijft en proactief blijft werken.

1 TNO Child Health, Leiden; 2 Academische Werkplaats Publieke Gezondheid - jeugd Noordelijk Zuid-Holland, Samen voor de jeugd

Informatie: magda.boere@tno.nl
Het ontwikkelen van de

JGZ-richtlijn Seksuele

\section{Ontwikkeling}

J.A. Deurloo, ${ }^{1}$ I. van der Vlugt, ${ }^{2}$ S. Maris, ${ }^{2}$ M. Kamphuis ${ }^{1}$ en C. Lanting ${ }^{1}$

\section{Achtergrond en doelstelling}

De seksuele ontwikkeling van kinderen begint al op jonge leeftijd en omvat zowel de lichamelijke als de psychosociale ontwikkeling. Het is een onderwerp dat veel vragen oproept, zowel bij ouders als bij kinderen, jongeren en professionals. Een positieve seksuele ontwikkeling vormt de basis voor het kunnen genieten van seksualiteit en kan veel problemen, zoals seksueel misbruik en tienerzwangerschappen, helpen voorkomen. Duidelijke en betrouwbare informatie over seksualiteit is onmisbaar voor ouders, kinderen en jongeren om goed onderbouwde keuzes te kunnen maken. Jeugdgezondheidszorg (JGZ) medewerkers kunnen een belangrijke rol spelen in de preventie en vroege signalering van problemen op het gebied van de seksuele ontwikkeling. Tevens kunnen zij bijdragen aan het stimuleren van een gezonde seksuele ontwikkeling en een positieve seksuele attitude.

\section{Methode}

Voor de ontwikkeling van de JGZrichtlijn is gebruik gemaakt van (inter)nationale richtlijnen, literatuurstudies, expertopinie en praktijkervaring. In een praktijktest hebben 35 JGZ-medewerkers met de richtlijn gewerkt en deze beoordeeld op knelpunten in de uitvoering en op randvoorwaarden voor de landelijke implementatie.

\section{Resultaten}

De richtlijn beschrijft de lichamelijke en psychosociale seksuele ontwikkeling van kinderen van 0-19 jaar. Verder worden determinanten van seksuele gezondheid en de mogelijkheden tot voorlichting, advies, begeleiding en signalering in de JGZ beschreven. De richtlijn biedt JGZ-medewerkers ondersteuning in het beoordelen van seksueel gedrag en het zo mogelijk normaliseren van dit gedrag. Hiervoor adviseert de richtlijn het gebruik van het 'Vlaggensysteem'. Het Vlaggensys- 